Dhaka Univ. J. Biol. Sci. 20(1): 57-63, 2011 (January)

\title{
OPTIMUM HARVEST FOR SUSTAINABLE YIELD OF FISH LIVE FOOD TUBIFICID WORMS
}

\author{
Anwar Hossain, Mohammad Shamsur Rahman and Mahmud Hasan* \\ Department of Fisheries, University of Dhaka, Dhaka-1000, Bangladesh
}

Key words: Tubificid worms, Live food, Optimum harvest, Sustainable yield

\begin{abstract}
The Optimum harvest suitable for sustainable yield of tubificid worms without affecting the future yield for a period of 60 days was determined. The media ingredients used to culture the worms were $20 \%$ wheat bran, $30 \%$ soybean meal, $20 \%$ mustard oil cake, $20 \%$ cow dung and $10 \%$ sand. A harvest level of $50 \mathrm{mg} / \mathrm{cm}^{2}$ (maximum yield; $518.93 \pm 14.36 \mathrm{mg} / \mathrm{cm}^{2}$ ) at ten days interval starting from 30 days of worms' inoculation was found suitable for sustainable yield in the later sampling durations. Results of this study have implications in increasing fish yield by producing reliable and sustainable yield of fish live foods tubificid worms.
\end{abstract}

\section{Introduction}

Tubificid worms have been found to be one of the best qualities live foods in rearing the larvae of hatchery produced catfishes, prawn and ornamental fishes. Catfishes contribute nearly $2.41 \%$ of total inland fish production in Bangladesh. ${ }^{(1)}$ Farming of shing Heteropneustes fossilis, magur Clarias batrachus, pabda Ompok spp., pangas Pangasius hypophthalmus, prawn Macrobachium rosenbergii etc. is becoming progressively more important as cash animals in Bangladesh mostly in Mymensingh area. Production and consistent supply of good quality fingerlings in sufficient quantity are essential to sustain this section of aquaculture industry. However, reliable supply of required quantity of live foods such as tubificid worms is still a bottleneck in the rearing processes of catfish fry and fingerlings. The quality of good seed largely depends on the proper feed management in which production of live foods in particular the tubificid worms in the rearing of catfish larvae is important.

Live foods enhance the growth and survival rates of juvenile catfishes, crustacean and ornamental fishes.(2) Significantly higher survival rates and ten-times extra growth was found in catfish Clarias batrachus larvae fed tubificid worms over those formulated dry feed.(3) Similar growth rate was detected in C. batrachus and C. gariepinus larvae rearing using tubificid worms.(4,5) White sturgeon (Acipenser transmontanus) grew $40 \%$ larger on tubificid worms compared to inanimate pellets. ${ }^{(6)}$ The tubificid worms have become an important component in commercial aquaculture as a live food source because of their high food values (5575/calg dry matter basis).(7,8) They grow in a place

*Corresponding author. <mhasan@univdhaka.edu>. 
with steady and continuous water flow with high organic detritus. The current total supply of these worms comes from wild harvests which are unreliable and inadequate in terms of demand. Harvest from the wild is hazardous to collect for unhealthy conditions. Information related to culture and sustainable production of tubificid worms in Bangladesh is meagre. Little success has been reported of several attempts to develop a technique to culture tubificid worms.(9-10)

Thus there is a need to develop a technique suitable to get reliable supply meeting the growing demand. Therefore, the present study was undertaken with a view to determining the suitable harvest level for sustainable yield of tubificid worms.

\section{Materials and Methods}

Tubificid worms were collected from different places of Mymensingh and cleaned by water flow and held in a flow-through-system. The worms were conditioned for 24 hours before inoculation into the culture culverts. The experiment was conducted between April and June, 2009 for 60 days.

The worms were cultured in indoor cemented culverts $\left(160 \times 25 \times 10 \mathrm{~cm}^{3}\right)$ system to protect them from rain and sunlight or any other natural hazards. At the beginning of the experiment, the culverts were washed and cleaned with fresh water. The culverts were connected with a flow-through-system in which subsurface well water was used. Each culvert was given continuous water spray by using a horizontal porous PVC pipe (180 $\mathrm{cm}$ long and $1 \mathrm{~cm}^{2}$ diameter). The experiment was conducted in the Department of Fisheries Biology and Genetics, Bangladesh Agricultural University, Mymensingh.

A $4 \times 4$ factorial design was employed in triplicates to study the effects of four different harvest levels $\left(30,40,50\right.$ and $\left.60 \mathrm{mg} / \mathrm{cm}^{2}\right)$ and four sampling durations (30, 40, 50 and 60 day) for the sustainable yield of tubificid worms.

The ingredients wheat bran (20\%), soybean meal (30\%), mustard oil cake (20\%), cowdung $(20 \%)$ and $10 \%$ sand were used. The ingredients were mixed with water to get wet for a period of seven days for enhanced decomposition. Successive mixing was done twice a day for better mineralization.

Culture media were placed and water flow was adjusted 24 hours before inoculation of worms to the culverts. The collected tubificid worms were inoculated at the rate of 2.5 $\mathrm{mg} / \mathrm{cm}^{2}$ (i.e. $10 \mathrm{cg} /$ culvert). They were spread over the media homogeneously as much as possible in each culvert.

Continuous water flow was maintained which was able to keep the dissolved oxygen in suitable range $\left(4-6 \mathrm{mg} / \mathrm{cm}^{2}\right)$. The water flow rate was maintained by adjustment stop cork of PVC pipes.

The periodic supply of culture media was done after 10 days of worms' inoculation. The prepared media were introduced at the rate of $250 \mathrm{mg} / \mathrm{cm}^{2}$ in respective culverts 
once in every 10 days at 10.00 a.m. before sampling. Total quantity of media was spread through out the culverts. At that time, water flow was stopped for a while.

Water flow rate $(\mathrm{L} / \mathrm{min})$ was measured once in ten days. Water temperature $\left({ }^{\circ} \mathrm{C}\right)$ of the culture culverts and dissolved oxygen $(\mathrm{mg} / \mathrm{l})$ was detected with the help of a portable dissolved oxygen meter (Jenway, Model No. 9070, UK) before sampling at 10.00 a.m. once in every 10 days.

Samples were drawn at 30, 40, 50 and 60 day of 60 days culture duration. Samples were collected by using a sampler $\left(4.4 \times 4.4 \mathrm{~cm}^{2}\right)$ with water and media from five randomly selected places of each culvert. The worms were cleared by flowing water and separated with a pair of forceps and dropper from the unwanted particles. Cleaned tubificid worms were dried with blotting paper and weighed by Matler electric balance (Switzerland) graduated in $0.000 \mathrm{~g}$.

Data were analyzed by using ANOVA followed by Tukey's HSD post hoc for multiple comparisons. Data have been presented as mean \pm SEM and analyzed by using the statistical software SPSS version 11.5 with the level of significance at $\mathrm{p}<0.05$.

\section{Results and Discussion}

This experiment was conducted to determine the sustainability of the culture of tubificid worms by harvesting suitable quantity so that the post harvest population can remain unaffected for future harvests. It was observed that $50 \mathrm{mg} / \mathrm{cm}^{2}$ harvest resulted in the best yield $\left(379.00 \pm 40.95 \mathrm{mg} / \mathrm{cm}^{2}\right)$ while $60 \mathrm{mg} / \mathrm{cm}^{2}$ did the lowest $(216.48 \pm 25.64 \mathrm{mg}$ $\mathrm{cm}^{-2}$; Fig. 1). Harvests of 30 and $40 \mathrm{mg} \mathrm{cm}^{-2}$ had similar effects on the population growth which was significantly lower than in $50 \mathrm{mg} / \mathrm{cm}^{2}$ and higher than $\mathrm{did} 60 \mathrm{mg} / \mathrm{cm}^{2}$ harvests. While culture durations were compared, 60 day sampling had the highest yield of worms $\left(395.58 \pm 26.03 \mathrm{mg} / \mathrm{cm}^{2}\right)$ which was 2.91 -folds higher than that of the harvest of the first sampling that was the lowest $\left(135.76 \pm 9.49 \mathrm{mg} / \mathrm{cm}^{2}\right)$ observed in 30 day sampling (Fig. 2). Yield of 50 day sampling $\left(357.25 \pm 22.72 \mathrm{mg} / \mathrm{cm}^{2}\right)$ was similar but significantly higher than that of 40 day sampling $\left(294.39 \pm 20.52 \mathrm{mg} / \mathrm{cm}^{2}\right)$.

In case of sustainable yield of tubificid worms, the observed highest yield was found for the overall effects of different harvest levels when the harvest level was $50 \mathrm{mg} / \mathrm{cm}^{2}$ at a 60-day-sampling.

The highest $518.93 \pm 14.36 \mathrm{mg} / \mathrm{cm}^{2}$ was found at 60 day sampling when the sample size was $50 \mathrm{mg} \mathrm{cm}^{-2}$ worms (Fig. 3a-d). In $30 \mathrm{mg} / \mathrm{cm}^{2}$ sample, harvest level had similar trend at 40, 50 and 60-day-sampling but 30 day yield was significantly different from others. In harvest level $40 \mathrm{mg} \mathrm{cm}^{-2}$, the highest yield was found at 60 day had similar to 50 day yield but different from 30 and 40-day-yield. On the other hand, the harvest level of $60 \mathrm{mg} / \mathrm{cm}^{2}$ showed similar trends at 50 and 60-day-yields. 


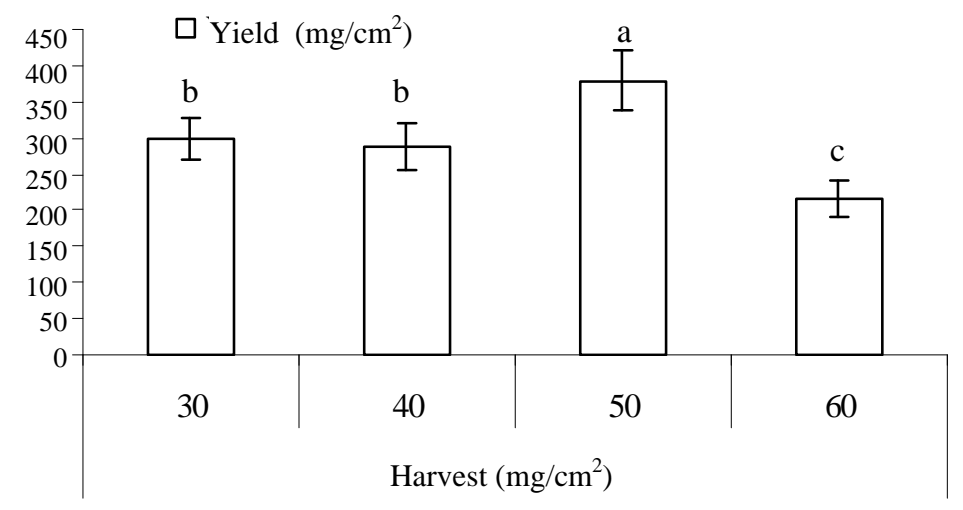

Fig. 1. Yield of tubificid worms after harvesting 30, 40, 50 and $60 \mathrm{mg} / \mathrm{cm}^{2}$ across all four sampling durations (30, 40,50 and 60 days). Bars ( \pm SEM) with different super script letters indicate significant differences (ANOVA, HSD; $\mathrm{p}<0.05)$.

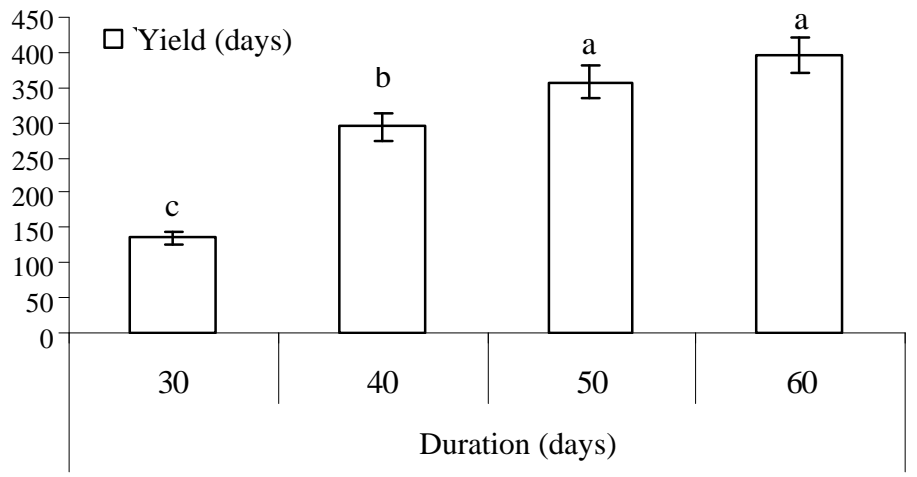

Fig. 2. Yield of tubificid worms sampled 30,40,50 and 60 days after inoculation across all four harvest levels $\left(30,40,50\right.$ and $\left.60 \mathrm{mg} / \mathrm{cm}^{2}\right)$. Bars $( \pm$ SEM) with different super script letters are significantly different (ANOVA, HSD; $\mathrm{p}<0.05$ ).

The observed maximum standing yield $\left(518.93 \mathrm{mg} / \mathrm{cm}^{2}\right)$ over 60 days culture was found in the media treatment (20\% WB, 30\% SM, 20\% MOC, $20 \% \mathrm{CD}$ and $10 \%$ sand) when $50 \mathrm{mg} / \mathrm{cm}^{2}$ worms have been harvested at every ten days interval. It has clearly been proved the suitability of the quantity to be harvested to maintain the post-harvest population that could be sustainable for future harvest. A little bit higher yield ( 852.43 $\mathrm{mg} / \mathrm{cm}^{2}$ ) has been found ${ }^{(10)}$ than the yield of present study by harvesting $30 \mathrm{mg} / \mathrm{cm}^{2}$ with same harvest interval but they needed 2.67-folds longer duration which of course makes the study impractical and economically nonviable. Because cost associated with additional culture duration over 100 days has resulted only $134 \mathrm{mg} / \mathrm{cm}^{2}$ yield which clearly demonstrates the unsuitability of this harvest level and also culture duration. 
3(a) harvest level $30 \mathrm{mg} / \mathrm{cm}^{2}$

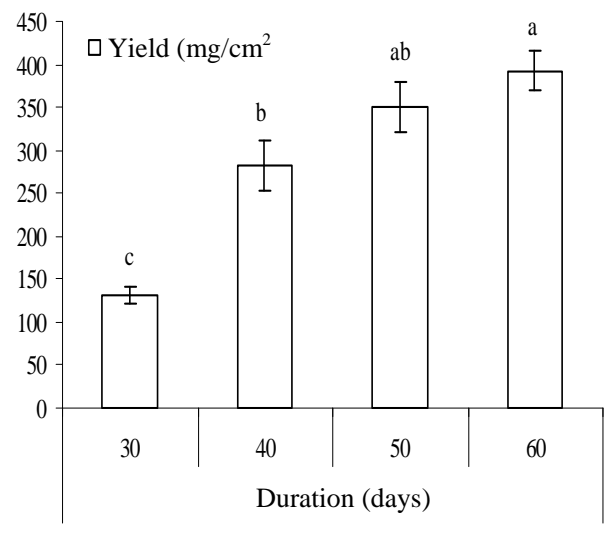

3(c) harvest level $50 \mathrm{mg} / \mathrm{cm}^{2}$

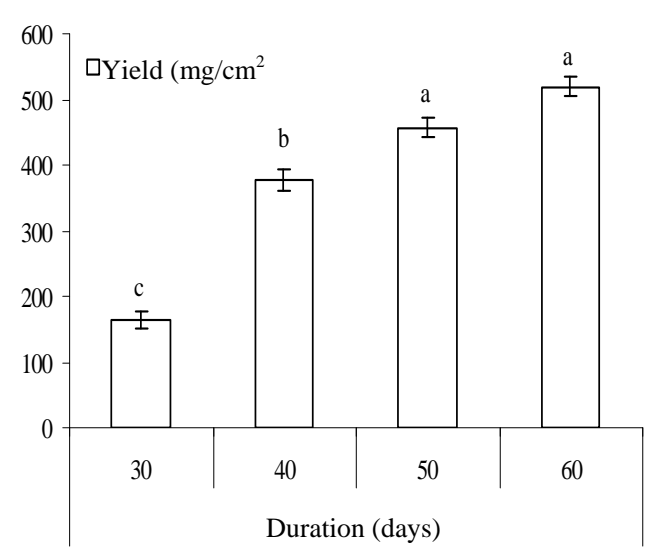

3(b) harvest level $40 \mathrm{mg} / \mathrm{cm}^{2}$

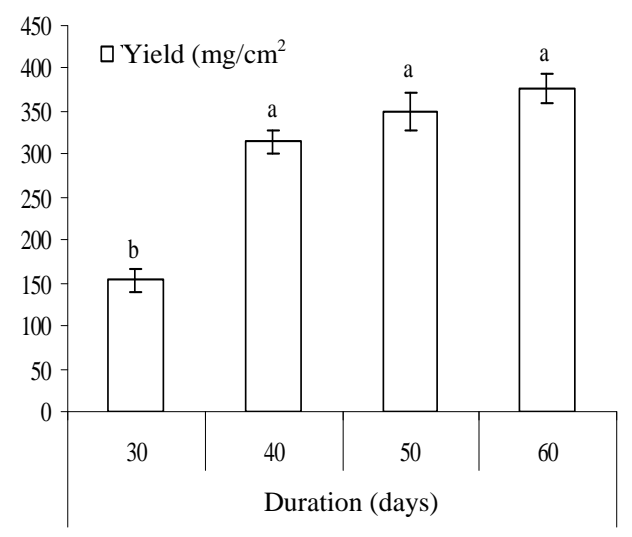

3(d) harvest level $60 \mathrm{mg} / \mathrm{cm}^{2}$

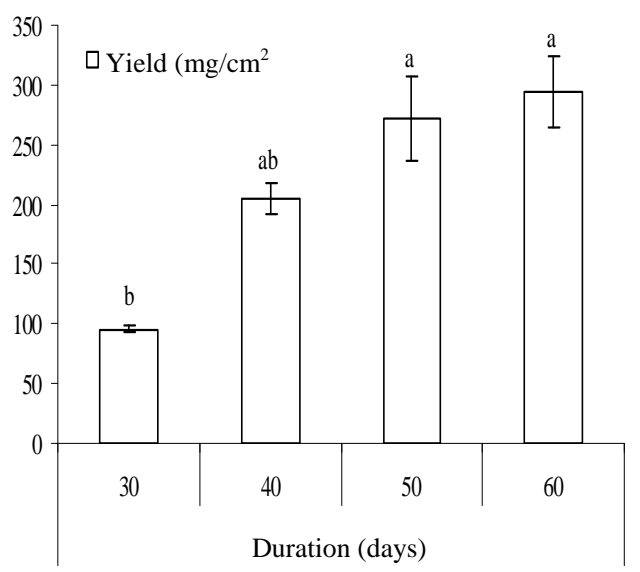

Fig. 3(a-d). Yield of tubificid worms sampled 30, 40, 50 and 60 days after inoculation across all four harvests (30, 40,50 and $60 \mathrm{mg} / \mathrm{cm}^{2}$ ) to determine the suitable harvest to maintain the sustainable population for future unaffected harvest. Bars $( \pm$ SEM) with different super script letters are significantly different (ANOVA, HSD; $\mathrm{p}<0.05)$.

The observed results showed that the harvest levels $30 \mathrm{mg} / \mathrm{cm}^{2}$ and $40 \mathrm{mg} / \mathrm{cm}^{2}$ were under-harvested because their initial standing biomass was gradually increased and then reached the carrying capacity of the culture system. And just after exceeding the level of carrying capacity of the culture system, the production of both treatments dropped because of sudden death of a considerable number of tubificid worms. The death might have occurred due to oxygen depletion $(2.1 \mathrm{mg} / \mathrm{l})$. The tubificid population usually distorted after the introduction of the media when the rate of decomposition of media was comparatively high needing enormous amount of oxygen. On the other hand, the harvest levels $60 \mathrm{mg} / \mathrm{cm}^{2}$ was over harvested because the remaining biomass decreased 
over the harvesting periods. Across the four treatments tested, the harvest levels 50 $\mathrm{mg} / \mathrm{cm}^{2}$ showed more sustainable condition than others. The remaining biomass was not affected in $50 \mathrm{mg} / \mathrm{cm}^{2}$ harvest level.

The total yield $718.93 \pm 14.36 \mathrm{mg} / \mathrm{cm}^{2}$ of tubificid worms (harvested yield $200 \mathrm{mg} / \mathrm{cm}^{2}$ and standing yield $518.93 \pm 14.36 \mathrm{mg} / \mathrm{cm}^{2}$ ) was found in $50 \mathrm{mg} / \mathrm{cm}^{2}$ harvest level that was higher than that of harvest level 30, 40 and $60 \mathrm{mg} \mathrm{cm}^{-2}$ at 60 days culture (Fig. 4).

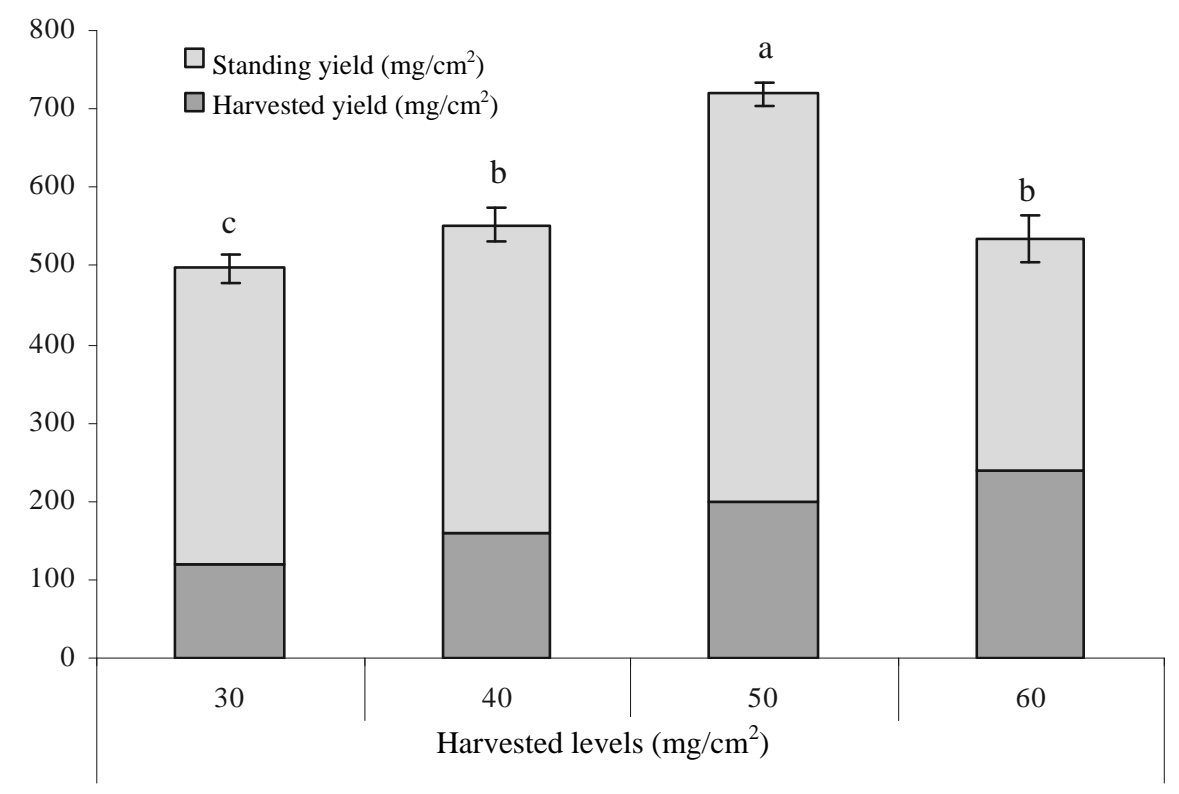

Fig. 4. Total yield of tubificid worms in different harvest levels (30, 40, 50 and $60 \mathrm{mg} \mathrm{cm}^{-2}$ ) for over 60 days culture period. Bars $( \pm$ SEM) with different super script letters are significantly different (ANOVA, HSD; $\mathrm{p}<0.05)$.

Temperature of the culverts water was ranged from 22 to $26^{\circ} \mathrm{C}$ throughout the study period. Water flow rate $(1.14-1.30 \mathrm{~L} / \mathrm{min})$ maintained the DO levels between 4 and $6 \mathrm{mg}$ $\mathrm{L}^{-1}$. In the entire experiment, the observed water temperature $\left(22\right.$ to $\left.26^{\circ} \mathrm{C}\right)$ and dissolved oxygen (4 to $6 \mathrm{mg} / \mathrm{L}$ ) indicates optimum limit with the water flow rate of 1.14 to1.30 $\mathrm{L} / \mathrm{min}$. ${ }^{(11)}$ The whole life cycle of Tubifex tubifex to be 100 to 123,70 to 90 and 28 to 64 days at 15,20 and $25^{\circ} \mathrm{C}$ environment temperature, respectively, hafd been studied earlier. ${ }^{(12)}$ While $11.0^{\circ} \mathrm{C}$ is the minimum temperature for the reproduction of $T$. tubifex, 2.5 and $38.0^{\circ} \mathrm{C}$ are lethal. ${ }^{(13)}$

The result has shown that $50 \mathrm{mg} / \mathrm{cm}^{2}$ can be considered as the optimal and balanced harvest level to get the sustainable production of tubificid worms in the future harvest. 


\section{References}

1. FRSS. 2007-08. Fisheries Resources Survey System. Department of Fisheries (DoF), Bangladesh.

2. Proulx O and J De La None 1985. Growth of daphnia magma on urban sp. Water tertiarity treated with Scenedesmus sp. Aquacul. Eng. 4: 93-11.

3. Alam MS and MFA Mollah 1988. Formulation of an artificial dry feed for primary nursing of catfish (Clarias batrachus L) larvae. Bangladesh J. Fish. 11 (1): 71-75.

4. Mollah MFA and M Nurullah 1988. Effects of feeding frequency on the growth and survival of catfish (Clarias batrachus) larvae. Bangladesh J. Fish. 11 (2): 9-14.

5. Mollah MFA 1991. Culture feasibility of African catfish (Clarias gariepinus) in Bangladesh. Bangladesh J. Fish. 14: 87-89.

6. Buddington PK and SJ Doroshov 1984. Feeding trials with hatchery produced white sturgeon (Acipenser transmontanus). Aquaculture 36: 237-243.

7. Giere O and O Pfannkuche 1982. Biology and ecology of marine oligochaete, a review. In: M. Barnes (ed.), Oceanography and Marine Biology, Aberdeen University Press. pp. 173-308.

8. Lietz DM 1987. Potential for aquatic oligochaetes as live food in commercial aquaculture. Hydrobiol. 155: 309-310.

9. Mollah MFA and MT Ahamed 1989. A note on preliminary study of culture of Tubificids worms. Bangladesh J. Fish. 12 (2), 91-95.

10. Ahamed MT and MFA Mollah 1993. Effects of various levels of wheat bran and mustard oil cake in the culture media on Tubificid production. Aquaculture 107: 107-113.

11. Marian MP and TJ Pandian 1985. Culture and harvesting techniques of Tubifex tubifex. Aquaculture 42: 303-345.

12. Li RenXi 2001. Studies on the growth and reproduction of Tubifex tubifex Muller. ActaHydrobiol.-Sinica. 25 (1): 14-20.

13. Korotun MM 1959. The rate of reproduction in certain fresh water oligochaeta, in relation to environmental condition. Zool. Zh. 38: 38-46.

(Manuscript received on 28 June, 2010; revised on 2 August, 2010) 